\title{
Virucidal Efficacy of Guanidine-Free Inactivants and Rapid Test Buffers Against SARS-CoV-2: Implications for Risk Assessment of Diagnostic Procedures
}

Katherine Davies

Public Health England

Ulrike Arnold

Public Health England Hubert Buczkowski

Public Health England

Christopher Burton

Public Health England

Stephen R Welch

Public Health England

Nicole Green

Public Health England

Rhea Strachan

Public Health England

Tracy Beetar-King

Public Health England

Peter Spencer

Public Health England

Nipunadi Hettiarachchi

Public Health England

Matthew J Hannah

Public Health England

Matthew Jones

Public Health England

Patricia A Cane

Public Health England

Christine B Bruce

Public Health England

Neil Woodford

Public Health England 


\section{Allen DG Roberts \\ Public Health England \\ Marian J Killip ( $\sim$ marian.killip@phe.gov.uk)}

Public Health England

\section{Research Article}

Keywords: COVID-19, SARS-CoV-2, inactivation, lysis buffers, coronavirus, specimen transport media, lateral flow test, diagnostics, safety testing

Posted Date: June 16th, 2021

DOl: https://doi.org/10.21203/rs.3.rs-579587/v1

License: (c) (i) This work is licensed under a Creative Commons Attribution 4.0 International License.

Read Full License 
1 Virucidal Efficacy of Guanidine-Free Inactivants and Rapid Test Buffers against

2 SARS-CoV-2: Implications for Risk Assessment of Diagnostic Procedures

4 Authors:

$5 \quad$ Katherine Davies ${ }^{1}$, Ulrike Arnold ${ }^{1}$, Hubert Buczkowski ${ }^{1}$, Christopher Burton ${ }^{1}$, Stephen

6 R Welch ${ }^{1}$, Nicole Green ${ }^{1}$, Rhea Strachan ${ }^{1}$, Tracy Beetar-King ${ }^{1}$, Peter Spencer ${ }^{1}$,

7 Nipunadi Hettiarachchi ${ }^{1}$, Matthew J Hannah ${ }^{1}$, Matthew Jones ${ }^{1}$, Patricia A Cane ${ }^{1}$,

8 Christine B Bruce ${ }^{1}$, Neil Woodford ${ }^{2}$, Allen DG Roberts ${ }^{1}$, Marian J Killip ${ }^{1 \#}$

9

Affiliations:

${ }^{1}$ High Containment Microbiology, NIS Laboratories, National Infection Service, Public Health England, London, NW9 5EQ

${ }^{2}$ NIS Laboratories, National Infection Service, Public Health England, London, NW9 $5 E Q$

Running Title: SARS-CoV-2 Inactivation by Guanidine-Free and Rapid Test Buffers

\#Corresponding author: marian.killip@phe.gov.uk

Key Words: COVID-19; SARS-CoV-2; inactivation; lysis buffers; coronavirus; specimen transport media; lateral flow test; diagnostics; safety testing 


\section{Abstract}

27 A pathogen inactivation step during collection or processing of clinical samples has 28 the potential to reduce infectious risks associated with diagnostic procedures. It is 29 essential that these inactivation methods are demonstrated to be effective, particularly 30 for non-traditional inactivation reagents or for commercial products where the chemical 31 composition is undisclosed. This study assessed inactivation effectiveness of twenty32 four next-generation (guanidine-free) nucleic acid extraction lysis buffers and twelve 33 rapid antigen test buffers against SARS-CoV-2, the causative agent of COVID-19.

34 These data have significant safety implications for SARS-CoV-2 diagnostic testing and support the design and evidence-based risk assessment of these procedures. 
37 The international response to the COVID-19 pandemic has required diagnostic testing of a vast number of patient samples worldwide for the detection of SARS-CoV- $2^{1}$. SARS-CoV-2 is classified as a Hazard Group 3 (HG3) pathogen in the UK by the Advisory Committee for Dangerous Pathogens due to its potential to cause severe respiratory disease; propagative work for any purpose must be carried out at containment level $3(\mathrm{CL} 3)^{2}$, which can severely restrict testing capabilities. Due to the exceptional circumstances presented by COVID-19, non-propagative diagnostic 
61 that reduces the titre of infectious virus present e.g. by eluting samples into an effective lysis buffer.

63

The chaotropic agents guanidine thiocyanate (GTC) and guanidine hydrochloride

$(\mathrm{GHCl})$ are commonly used to inactivate viruses prior to nucleic acid testing ${ }^{5}$ and guanidine-based lysis buffers are effective at reducing SARS-CoV-2 titre ${ }^{6,7}$. However, reagents containing $\mathrm{GTC}$ and $\mathrm{GHCl}$ are a chemical hazard in testing laboratories due to their toxicity and incompatibility with sodium hypochlorite-based disinfectants ${ }^{8}$. Their hazardous nature also limits use of $\mathrm{GTC}$ and $\mathrm{GHCl}$ buffers in home-sampling kits because of the potential for misuse by members of the public. There are now many commercial non-hazardous alternatives to guanidine-based lysis buffers; these would prove valuable additions to COVID-19 testing procedures if effective at inactivating SARS-CoV-2. Currently, there is limited information available on the efficacy of SARSCoV-2 inactivation by either guanidine-free lysis buffers or by rapid test buffers. This test buffers.

\section{Methods}

All handling of infectious SARS-CoV-2 was performed inside Class III MSCs within a CL3 facility. SARS-CoV-2 (England/02/2020) was propagated in Vero E6 cells (Vero C1008; ATCC CRL-1586) as previously described ${ }^{6}$. Virus was used in inactivation tests at passage 2 or 3 (with virus titres of approximately $1 \times 10^{7}$ PFU per $\mathrm{ml}$ ). Approximately 10-fold concentrated SARS-CoV-2 virus stocks (approximately $1 \times 10^{8}$ 
PFU per ml) were produced by centrifuging SARS-CoV-2 supernatant through Amicon Ultra-15 (100K) filters (Millipore) according to the manufacturer's instructions.

Guanidine-free lysis buffers and LFIA tests kit buffers evaluated and the active ingredients of these products where disclosed are listed in Table 1. Inactivation testing was performed essentially as previously described ${ }^{6}$. In brief, SARS-CoV-2 was incubated with nucleic acid extraction buffers at a ratio and contact time indicated by the manufacturer's instructions, where these were available. LFIA buffers were tested after a 1-minute treatment time, to mimic likely contact times in real-life testing scenarios. 5- and 10-minute treatment times were additionally evaluated to determine the effect of longer incubation times. For most products, treated samples were passed through a filtration matrix (Detergent Removal Resin [Pierce], Sephadex LH-20 [GE Healthcare], Sephacryl S-400HR [Sigma-Aldrich] or BioBeads SM2 [Biorad]) to remove cytotoxic chemicals prior to virus titration to improve the limit of detection $(\text { LOD })^{6}$. The optimum purification method for each product was assessed as previously described ${ }^{6}$, and is listed in Table 1. After sample clean-up, samples were 10-fold serially diluted in PBS and plated on to 96-well plates containing $2.5 \times 10^{4}$ Vero E6 cells. Plates were incubated for $6-7$ days at $37^{\circ} \mathrm{C} / 5 \% \mathrm{CO}_{2}$, then fixed and stained with crystal violet to visualise cytopathic effect (CPE). The 50\% tissue culture infectious dose $\left(\mathrm{TCID}_{50}\right)$ was calculated according to the Spearman-Karber method ${ }^{9}$. As a control for virus recovery, SARS-CoV-2 was mock-treated with PBS in parallel, at the same ratio as the reagent being tested. PBS-treated samples were subjected to the same filtration and titration methods as product-treated samples. All tests were carried out in triplicate and titre reduction was calculated by subtracting the mean $\log _{10}$ titre of tested samples from the mean $\log _{10}$ titre of PBS controls. A cytotoxicity control 
was purified (if applicable) and titrated alongside other test samples, and used to determine the LOD for each test; this control consisted of PBS in place of virus, treated with an equivalent volume of product as test samples. $95 \%$ confidence intervals for titre reductions were calculated as mean $\log _{10}$ titre reduction \pm 1.96 standard error ${ }^{9}$. Products were tested against an unconcentrated SARS-CoV-2 stock as standard. Concentrated virus preparations were used to increase the maximum possible titre reduction for products (indicated in Table 1) that displayed high levels of cytotoxicity and/or that were previously found to reduce the titre of unconcentrated virus to below the test LOD.

\section{Results}

The guanidine-free lysis buffers listed in Table 1 were tested for their ability to inactivate SARS-CoV-2. These reagents are variously marketed as appropriate for lysis of different sample types, including nasopharyngeal/oropharyngeal swabs, sputum and saliva, prior to nucleic acid extraction or as inactivating specimen transport media. A >4.0 $\log _{10}$ reduction in SARS-CoV-2 titre, required by the British European standard BS EN 14476 for quantitative virucidal suspension tests ${ }^{9}$, was demonstrated for most guanidine-free nucleic acid extraction buffers tested (Table 1 and Figure 1A), including: virusPHIX+, virusPHIX-LV and virusPHIX-P9; VitaPCR Sample Collection Buffer; MELT Medium B, V3 and V4; D-Biotech Virus Preservation Solution; ID NOW COVID-19 Elution Buffer (after a 5-minute treatment); OMNIgene Oral; PROmate Sample Preparation Buffer containing either Triton X-100 or Triton X-100 reduced; Zeesan Saliva RNA Sample Collector Kit buffer; Zeesan Viral RNA Collection Kit buffer (after 30 minutes); IsoHelix GeneFix and Buccalfix buffers; GeneMe FRANKD (after 5 minutes) and SAVD buffers. 
Of the molecular extraction reagents tested, we failed to demonstrate $>4.0 \log _{10}$ reduction in SARS-CoV-2 titre for Salicovgel-1 (1.0 $\log _{10}$ after 1 hour), Salicovgel-2 (3.1 and $\geq 3.4 \log _{10}$ reduction after 1 and 3 hours, respectively), MicroLYSIS-RNA (1.0 $\log _{10}$ reduction after the recommended 5 minute contact time and $1.9 \log _{10}$ reduction after 20 minutes), virusPHIX-CU (1.0 $\log _{10}$ reduction after 30 minutes) and Arcis Coronavirus Extraction Reagent 2506 ( $\geq 3.3 \log _{10}$ reduction after 10 minutes) (Table 1 and Figure 1A). Testing of the Arcis product using a 10-fold concentrated SARS-CoV2 preparation to improve the maximum detectable titre reduction demonstrated only a

$0.7 \log _{10}$ reduction after 10 minute treatment suggesting this buffer may be less effective with high concentrations of virus or protein (Table 1 and Figure 1A). contact time (Table 2 and Figure 1B). 


\section{Discussion}

Incorporation of novel products into existing diagnostic workflows requires them to be effective at inactivating pathogens; this study has provided inactivation efficacy data for twenty-four new products against SARS-CoV-2. Many new nucleic acid extraction reagents are guanidine-free and their inclusion in diagnostic procedures in place of hazardous guanidine-based reagents has the potential to eliminate the chemical hazards associated with guanidine use. Furthermore, many new products are supplied as non-hazardous: non-hazardous inactivating specimen transport media have the potential to increase the safety of sample transport and the speed of testing processes while not posing a chemical hazard to users at the sampling stage. SARS-CoV-2 inactivation effectiveness of twelve buffers provided with LFIA tests was additionally evaluated in this study, since these are being increasingly employed as COVID-19 testing capabilities are scaled up to include home and workplace testing.

Of the products that were demonstrated to inactivate SARS-CoV-2 effectively (i.e. $>4$ $\log _{10}$ reduction in titre following treatment), four nucleic acid extraction buffers (MELT medium B, D-Biotech Virus Preservation Solution, Abbott ID NOW Elution Buffer, PROmate Sample Preparation Buffer, and two LFIA buffers (BD Veritor and Schebo) are known to contain the non-denaturing detergent Triton $\mathrm{X}-100$ as an active ingredient; we and others have previously shown that the Triton X-100 is effective at reducing SARS-CoV-2 titres by $>5-6 \log _{10} 6,10$. Commercial products containing Triton X-100 reduced (PROmate and MELT V3), Triton CG-110 (MELT V4), SDS (OMNIgene Oral), trifluoroacetamide/trimethylglycine (virusPHIX+, -LV and -P9), sodium hydroxide (VitaPCR), sodium lauroyl sarcosinate (Zeesan Saliva RNA Collector Kit buffer) were also effective at reducing SARS-CoV-2 infectivity. Several guanidine-free 
products (Geneme FRANKD and SAVD buffers, GeneFix and BuccalFix) and one LFIA buffer (Mologic) were effective but information on chemical composition for these buffers has not been disclosed by the manufacturers. Enzymatic inactivation may be an alternative to chemical inactivation, and the inactivation of viruses has been previously demonstrated using proteolytic enzymes ${ }^{11}$. Virucidal activity of the enzymebased inactivants Salicovgel-1 and Salicovgel-2 were assessed in this study; while a $>4 \log 10$ titre reduction could not be demonstrated by either of these products, Salicovgel-2 reduced SARS-CoV-2 titre by $\geq 3 \log _{10}$ after 1 -hour treatment, indicating potential for enzymatic products as SARS-CoV-2 inactivants. Data presented in this study will aid testing laboratories that are required to replace Triton X-100 with Triton X-100 alternatives, due to the inclusion of Triton X-100 on the European Authorisation list (Annex XIV) of the Registration, Evaluation, Authorisation and Restrictions of Chemicals $(\mathrm{REACH})$ for phasing out of use ${ }^{12,13}$. In addition, several of the products shown to be effective inactivators of SARS-CoV-2 are marketed as non-hazardous specimen transport media, indicating that these may have potential for use in homesampling kits.

LFIA tests require mixing of a test swab or specimen with the buffer followed by use of a pipette or dropper to load a test cassette; the LFIA testing procedure may therefore lead to the generation of infectious aerosols. Furthermore, the infectious titre of samples tested directly after patient sampling (as is the case for POC tests) is likely to be higher than for those that are transported from sampling sites to testing laboratories before further handling. Inactivation efficacy of POC test buffers is a key consideration for risk assessment of POC testing processes: only three of the twelve LFIA buffers tested in this study were effective at inactivating SARS-CoV-2. Several LFIA buffers 
210 tested were completely ineffective against SARS-CoV-2 and of those that did reduce

211 virus titre, most gave modest reductions in comparison with other extraction buffers.

212 Data presented here indicate that testing centres should not rely upon LFIA buffers to 213 completely inactivate infectious samples and that additional control measures should 214 be implemented to ensure the protection of test operators.

216 Data on the effectiveness of any inactivation step is crucial for designing and risk assessing testing procedures. Findings presented here are relevant for SARS-CoV-2 diagnostic laboratories, testing centres and mass testing programmes worldwide, providing data to support evidence-based risk assessment of testing procedures.

\section{Acknowledgments}

This work was supported by Public Health England. The views expressed are those of the authors and not necessarily those of Public Health England or the Department of Health.

\section{$\underline{\text { References }}$}

1 Hasell, J. et al. A cross-country database of COVID-19 testing. Sci Data 7, 345, doi:10.1038/s41597-020-00688-8 (2020).

2 Public Health England. COVID-19: safe handling and processing for laboratories https://www.gov.uk/government/publications/wuhan-novelcoronavirus-guidance-for-clinical-diagnostic-laboratories/wuhan-novelcoronavirus-handling-and-processing-of-laboratory-specimens (2020). World Health Organization. Laboratory biosafety guidance related to coronavirus disease (COVID-19) 
https://www.who.int/publications/i/item/laboratory-biosafety-guidance-relatedto-coronavirus-disease-(covid-19) (2020).

237

4 Centers for Disease Control and Prevention. Guidance for SARS-CoV-2 Point-of-Care Testing. https://www.cdc.gov/coronavirus/2019-ncov/lab/pointof-care-testing.html (2020).

5 Farrell, R. E. RNA Isolation Strategies. Rna Methodologies: Laboratory Guide for Isolation and Characterization, 5th Edition, 75-115, doi:10.1016/B978-012-804678-4.00003-8 (2017).

6 Welch, S. R. et al. Analysis of Inactivation of SARS-CoV-2 by Specimen Transport Media, Nucleic Acid Extraction Reagents, Detergents, and Fixatives. J Clin Microbiol 58, doi:10.1128/JCM.01713-20 (2020).

7 Public Health England. COVID-19: PHE laboratory assessments of inactivation methods https://www.gov.uk/government/publications/covid-19phe-laboratory-assessments-of-inactivation-methods (2020).

8 U.S. Food and Drug Administration. Transport Media Safety Risk - Use Compatible Transport Media with SARS-CoV-2 Tests that Use Bleach - Letter to Clinical Laboratory Staff and Health Care Providers https://www.fda.gov/medical-devices/letters-health-care-providers/transportmedia-safety-risk-use-compatible-transport-media-sars-cov-2-tests-usebleach-letter (2020).

$9 \quad$ British Standards Institution. BS EN 14476:2013+A2:2019 - Chemical disinfectants and antiseptics. Quantitative suspension test for the evaluation of virucidal activity in the medical area. Test method and requirements (Phase 2/Step 1) (2013). 
25910 Patterson, E. I. et al. Methods of Inactivation of SARS-CoV-2 for Downstream Biological Assays. J Infect Dis 222, 1462-1467, doi:10.1093/infdis/jiaa507

261 (2020).

262

11 Amtmann, A. et al. Virucidal effects of various agents-including proteaseagainst koi herpesvirus and viral haemorrhagic septicaemia virus. $43,185-$ 195, doi:https://doi.org/10.1111/jfd.13106 (2020).

12 European Chemicals Agency. Authorisation List: List of substances included in Annex XIV of REACH https://echa.europa.eu/authorisation-list> (2021).

13 White, R., Jobling, S., Hoare, S. A., Sumpter, J. P. \& Parker, M. G. (1994).

\section{Author Contributions Statement}

KD, UA, HB, CB, SRW, NG, RS, TBK, NH, MJH, MJ and MJK conducted inactivation experiments; KD, PS and MJK analysed data; KD and MJK prepared the manuscript; PAC, CBB, NW, ADG and MJK conceived and designed the work. All authors reviewed the manuscript.

\section{Additional Information}

The authors declare no competing interests. 
Figure 1: SARS-CoV-2 titre reductions following treatment with guanidine-free molecular extraction reagents and LFIA buffers

288

SARS-CoV-2 suspension was treated with guanidine-free molecular extraction 290 reagents $(A)$ or LFIA buffers $(B)$, using the contact times and concentrations stated in Table 1 and Table 2, respectively. SARS-CoV-2 was mock-treated with an equivalent volume of PBS in parallel. Samples were purified by methods indicated in Table 1 and Table 2 to remove product-associated cytotoxicity, then titrated by TCID 50 on Vero E6 cells to determine virus titre. All treatments and mock-treatments were performed in triplicate; bars show the mean of sample triplicates and error bars the standard deviation of triplicates. The limit of detection for each test was determined using the cytotoxicity control for each test, and is indicated on the graph for each test by a dashed line. Where cytotoxicity of sample replicates and/or treatment times for a product differed, the highest LOD for the entire test is displayed. Variation in virus titres for PBS-treated samples between product tests was due to differences in the titre of virus stock used, the ratio of sample to product or PBS used for treatment, and differing virus recovery following sample filtration with different methods ${ }^{6}$. N.B. The test of Arcis reduced. 


\section{$310 \quad$ Figure 1}

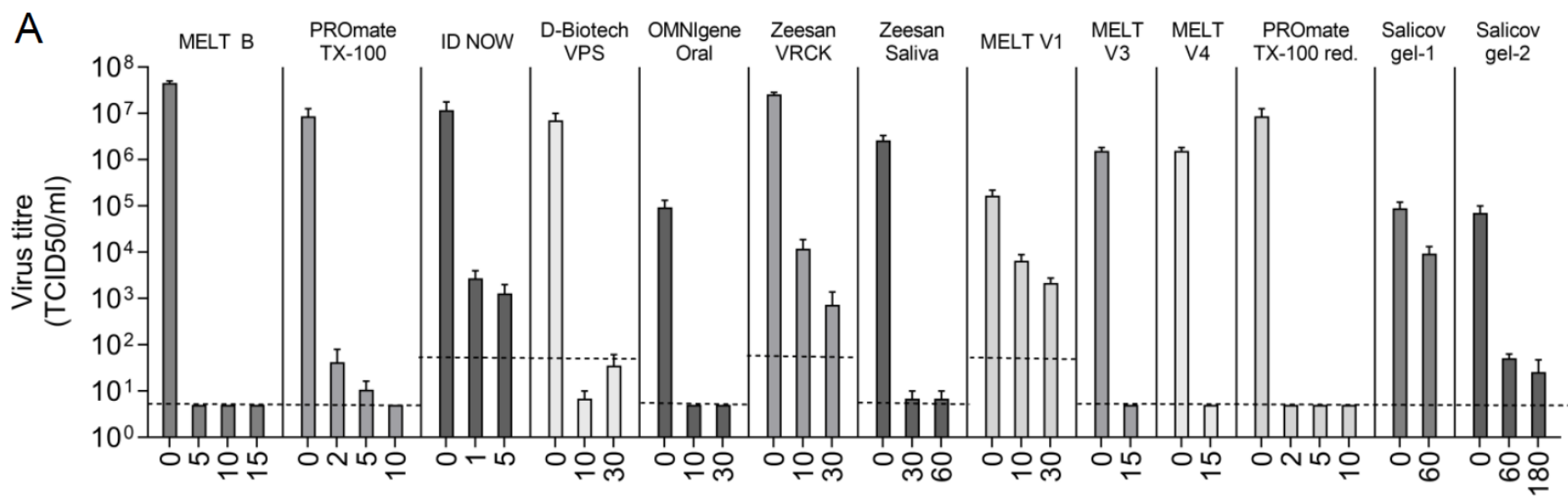

Treatment time (minutes)

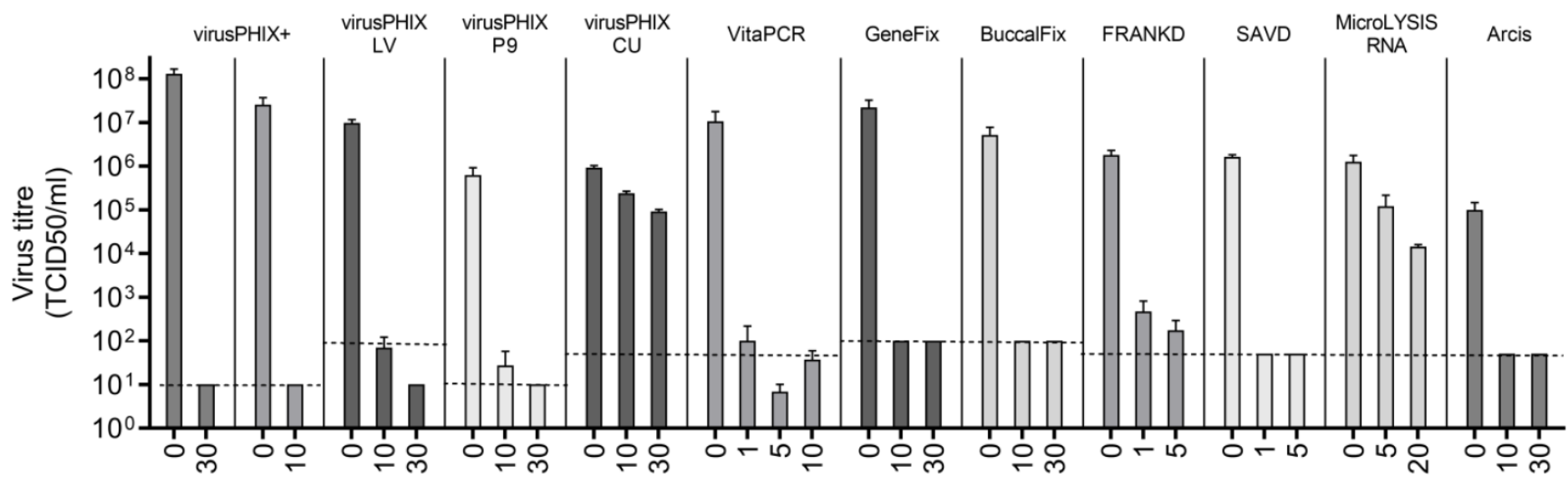

Treatment time (minutes)

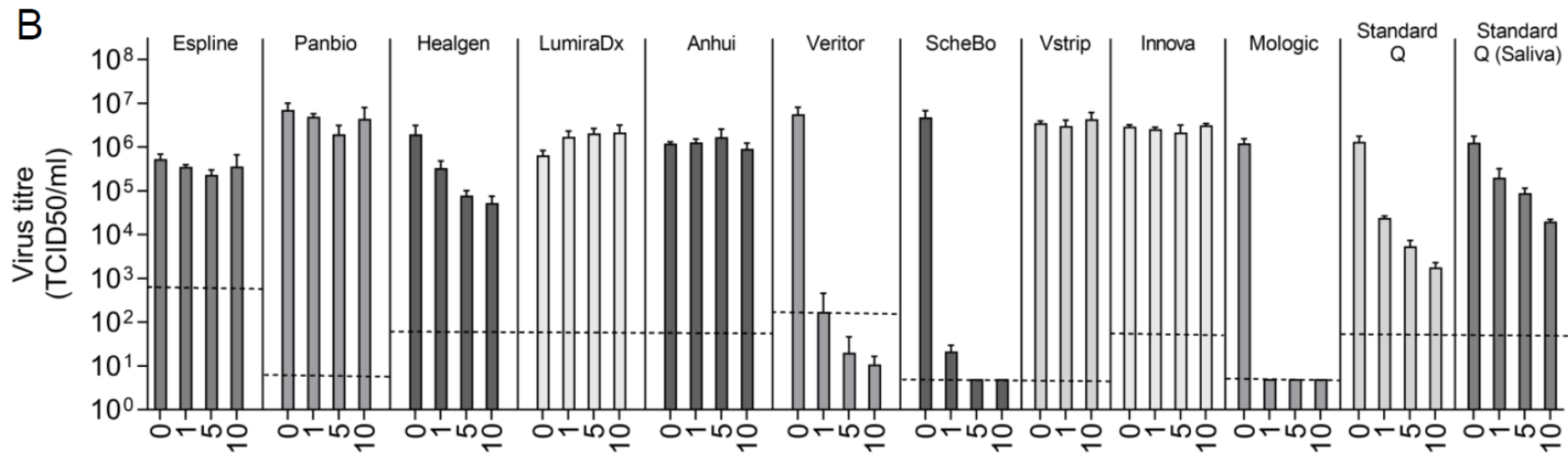

Treatment time (minutes) 
Table 1: SARS-CoV-2 inactivation by guanidine-free nucleic acid extraction reagents

\begin{tabular}{|c|c|c|c|c|c|c|}
\hline Product name (manufacturer) & Active ingredient/s, if known* & $\begin{array}{l}\text { Purification } \\
\text { resin }^{\ddagger}\end{array}$ & $\begin{array}{l}\text { Reagent: virus } \\
\text { ratio }\end{array}$ & $\begin{array}{l}\text { Contact time } \\
\text { (minutes) }\end{array}$ & $\begin{array}{l}\text { Titre reduction, } \\
\log _{10} \mathrm{TCID}_{50} / \mathrm{ml} \\
{\left[\begin{array}{l} \pm 95 \% \mathrm{Cl} \\
]^{\dagger}\end{array}\right.} \\
\end{array}$ & $\begin{array}{c}\text { Virus detectable in } \mathrm{TCID}_{50} \\
\text { (virus detected in } \mathrm{n} / \mathrm{N} \\
\text { replicates) }\end{array}$ \\
\hline virusPHIX+ (RNAssist) & $\begin{array}{l}20-90 \% \text { trifluoroacetamide } \\
20-90 \% \text { trimethylglycine }\end{array}$ & PDRR & $3: 1$ & $\begin{array}{l}10 \\
30\end{array}$ & $\begin{array}{l}\geq 6.4[6.2-6.7] \\
\geq 7.1[6.9-2.4]\end{array}$ & $\begin{array}{l}\mathrm{No}^{3} \\
\mathrm{No}^{3}\end{array}$ \\
\hline virusPHIX-LV (RNAssist) & $\begin{array}{l}20-50 \% \text { trifluoroacetamide } \\
20-50 \% \text { trimethylglycine }\end{array}$ & PDRR & $10: 1^{\#}$ & $\begin{array}{l}10 \\
30\end{array}$ & $\begin{array}{l}\geq 5.1[4.8-5.5] \\
\geq 6.0[5.7-6.3]\end{array}$ & $\begin{array}{l}\mathrm{No}^{4} \\
\mathrm{No}^{3}\end{array}$ \\
\hline virusPHIX-P9 (RNAssist) & $\begin{array}{l}2-5 \% \text { trifluoroacetamide } \\
1-3 \% \text { trimethylglycine }\end{array}$ & LH2O & $3: 1$ & $\begin{array}{l}10 \\
30\end{array}$ & $\begin{array}{l}\geq 4.4[4.1-4.6] \\
\geq 4.8[4.5-5.1]\end{array}$ & $\begin{array}{c}\text { Yes (1/3) } \\
\mathrm{No}^{3}\end{array}$ \\
\hline virusPHIX-CU (RNAssist) & Urea, choline chloride & None & $3: 1$ & $\begin{array}{l}10 \\
30\end{array}$ & $\begin{array}{l}0.6[0.1-1.0] \\
1.0[0.6-1.4]\end{array}$ & $\begin{array}{l}\text { Yes }(3 / 3) \\
\text { Yes (3/3) }\end{array}$ \\
\hline 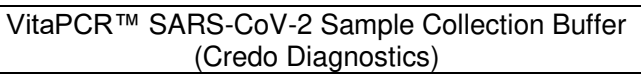 & $0.2 \%$ sodium hydroxide & PDRR & $10: 1^{\#}$ & $\begin{array}{l}1 \\
5\end{array}$ & $\begin{array}{c}\geq 5.0[4.7-5.3] \\
6.2[5.9-6.5]\end{array}$ & $\begin{array}{l}\text { Yes }(3 / 3) \\
\text { Yes }(3 / 3)\end{array}$ \\
\hline MELT Medium B (Mast Group) & $1-10 \%$ Triton $X-100$ & PDRR & $10: 1^{\#}$ & 5 & $\geq 7.0[6.6-7.3]$ & Yes $(1 / 3)$ \\
\hline MELT V1 (Mast Group) & $\begin{array}{c}\text { Ethylene oxide propylene oxide } \\
\text { copolymer mono (nonylphenyl) ether }\end{array}$ & PDRR & $10: 1$ & $\begin{array}{l}10 \\
30\end{array}$ & $\begin{array}{l}1.4[1.0-1.8] \\
1.9[1.5-2.2]\end{array}$ & $\begin{array}{l}\text { Yes }(3 / 3)^{1} \\
\text { Yes }(3 / 3)\end{array}$ \\
\hline MELT V3 (Mast Group) & Triton X-100 reduced & SM2 & $\frac{10: 1}{10 \cdot 1}$ & $\frac{15}{15}$ & $\geq 5.5[5.2-5.8]$ & $\mathrm{No}^{1}$ \\
\hline MELT V4 (Mast Group) & Triton CG-110 & SM2 & $10: 1$ & 15 & $\geq 5.5[5.2-5.8]$ & $\mathrm{No}^{1}$ \\
\hline Virus Preservation Solution (D-Biotech) & $\begin{array}{c}\text { Citric acid } \\
<0.1 \% \text { Triton } X-100\end{array}$ & PDRR & $10: 1^{\#}$ & $\begin{array}{l}10 \\
30\end{array}$ & $\begin{array}{l}\geq 6.0[5.7-6.3] \\
\geq 5.3[5.0-5.6]\end{array}$ & $\begin{array}{l}\text { Yes (2/3) } \\
\mathrm{No}^{2}\end{array}$ \\
\hline ID NOW COVID-19 Elution Buffer (Abbott) & $0.1 \%$ Triton $X-100$ & PDRR & $25: 1^{\#}$ & $\begin{array}{l}1 \\
5\end{array}$ & $\begin{array}{l}3.6[3.2-4.0] \\
4.0[3.6-4.4]\end{array}$ & $\begin{array}{l}\text { Yes }(3 / 3) \\
\text { Yes }(3 / 3)\end{array}$ \\
\hline OMNIgene Oral (DNA Genotek) & $1-5 \%$ SDS & S400HR & $1: 1$ & 10 & $\geq 4.3[4.0-4.6]$ & $\mathrm{No}^{1}$ \\
\hline $\begin{array}{l}\text { COVID-19 PROmate Sample Preparation Buffer } \\
\text { with standard Triton X-100 (Novacyt) }\end{array}$ & $0.5 \%$ Triton $\mathrm{X}-100$ & SM2 & $10: 1^{\#}$ & $\begin{array}{c}2 \\
5 \\
10 \\
\end{array}$ & $\begin{array}{l}5.3[5.0-5.7] \\
5.9[5.6-6.2] \\
\geq 6.2[5.9-6.6] \\
\end{array}$ & $\begin{array}{l}\text { Yes }(3 / 3) \\
\text { Yes }(3 / 3) \\
\text { Yes }(1 / 3) \\
\end{array}$ \\
\hline $\begin{array}{l}\text { COVID-19 PROmate Sample Preparation Buffer } \\
\text { with Triton X-100 reduced (Novacyt) }\end{array}$ & $0.5 \%$ Triton $\mathrm{X}-100$ reduced & SM2 & $10: 1^{\#}$ & 2 & $\geq 6.2[5.9-6.6]$ & Yes $(2 / 3)$ \\
\hline Saliva RNA Sample Collector Kit (Zeesan) & $5-15 \%$ sodium lauroyl sarcosinate & PDRR & $2: 1$ & 30 & $\geq 5.6[5.3-5.9]$ & Yes (2/3) \\
\hline Virus RNA Collection Kit (Zeesan) & $5-10 \%$ sodium lauroyl sarcosinate & SM2 & $2: 1$ & $\begin{array}{l}10 \\
30 \\
\end{array}$ & $\begin{array}{l}3.3[2.9-3.7] \\
4.5[4.3-4.8]\end{array}$ & $\begin{array}{l}\text { Yes }(3 / 3) \\
\text { Yes }(3 / 3) \\
\end{array}$ \\
\hline Salicovgel-1 (LGC) & Enzymatic & S40OHR & $10: 1$ & 60 & $1.0[0.6-1.4]$ & Yes (3/3) \\
\hline Salicovgel-2 (LGC) & Enzymatic & S400 HR & $10: 1$ & $\begin{array}{c}60 \\
180\end{array}$ & $\begin{array}{c}3.1[2.9-3.4] \\
\geq 3.4[3.2-3.7]\end{array}$ & $\begin{array}{l}\text { Yes }(3 / 3) \\
\text { Yes }(2 / 3)\end{array}$ \\
\hline GeneFix Saliva RNA Collector (IsoHelix) & Not available & S400HR & $1: 1$ & 10 & $\geq 5.3[5.0-5.6]$ & $\mathrm{No}^{4}$ \\
\hline BuccalFix (IsoHelix) & Not available & S400HR & $5: 1^{\#}$ & 10 & $\geq 4.7[4.4-5.0]$ & $\mathrm{No}^{4}$ \\
\hline MicroLYSIS-RNA (Clent Life Science) & Not available & $\mathrm{S} 400 \mathrm{HR}$ & $1: 1$ & $\begin{array}{c}5 \\
20\end{array}$ & $\begin{array}{l}1.0[0.6-1.4] \\
1.9[1.6-2.3]\end{array}$ & $\begin{array}{l}\text { Yes }(3 / 3) \\
\text { Yes }(3 / 3)\end{array}$ \\
\hline & & & $2: 1$ & 10 & $\geq 3.3[3.0-3.6]$ & $\mathrm{No}^{5}$ \\
\hline $\begin{array}{l}\text { Coronavirus Extraction Reagent } 2506 \\
\text { (Arcis Biotechnology) }\end{array}$ & Not available & None & $2: 1^{\#}$ & $\begin{array}{l}10 \\
30\end{array}$ & $\begin{array}{l}0.7[0.3-1.2] \\
2.6[2.3-3.0]\end{array}$ & $\begin{array}{l}\text { Yes }(3 / 3) \\
\text { Yes }(3 / 3)\end{array}$ \\
\hline FRANKD Buffer (GeneMe) & Not available & PDRR & $10: 1$ & $\begin{array}{l}1 \\
5\end{array}$ & $\begin{array}{l}3.6[3.3-3.9] \\
4.0[3.7-4.3]\end{array}$ & $\begin{array}{l}\text { Yes }(3 / 3) \\
\text { Yes }(3 / 3)\end{array}$ \\
\hline SAVD Buffer (GeneMe) & Not available & PDRR & $4: 1$ & 1 & $\geq 4.5[4.2-4.8]$ & $\mathrm{No}^{5}$ \\
\hline
\end{tabular}

312 See overleaf for table footnotes 
313 Where identical results were obtained at multiple contact times, only the shortest contact time is shown

314 *As indicated on product safety data sheets or other product literature

315 TValues are given as $\geq$ when at least one replicate was below the limit of detection

316 \#Tested using concentrated virus stock

317 IPDRR: Pierce Detergent Removal Resin; SM2: Biorad SM2 BioBeads; S400HR: Sephacryl S-400HR; LH20: Sephadex LH-20

318 STM: Specimen transport media

319 Limit of detection: ${ }^{1} 0.7 \log _{10} \mathrm{TCID} 50 / \mathrm{mL} ;{ }^{2} 0.8 \log _{10} \mathrm{TCID} 50 / \mathrm{mL} ;{ }^{3} 1.0 \log _{10} \mathrm{TCID} \mathrm{D}_{50} / \mathrm{mL} ;{ }^{42} 2.0 \log _{10} \mathrm{TCID} \mathrm{D}_{50} / \mathrm{mL} ;{ }^{51.7} \log _{10} \mathrm{TCID} 50 / \mathrm{mL}$ 
Table 2: SARS-CoV-2 inactivation by rapid antigen test buffers

\begin{tabular}{|c|c|c|c|c|c|c|}
\hline Product name (manufacturer) & Active ingredient/s, if known* & $\begin{array}{c}\text { Purification } \\
\text { resin }^{\ddagger}\end{array}$ & $\begin{array}{c}\text { Reagent: } \\
\text { virus ratio }\end{array}$ & $\begin{array}{c}\text { Contact time } \\
\text { (minutes) }\end{array}$ & $\begin{array}{c}\text { Titre reduction, } \\
\log _{10} \mathrm{TClD}_{50} / \mathrm{ml} \\
{[ \pm 95 \% \mathrm{Cl})^{\dagger}}\end{array}$ & $\begin{array}{c}\text { Virus detectable in } \mathrm{TCID}_{50} \\
\text { (virus detected in } \mathrm{n} / \mathrm{N} \\
\text { replicates) }\end{array}$ \\
\hline $\begin{array}{l}\text { ESPLINE® SARS-CoV-2 } \\
\text { Extraction Solution (Fujirebio) }\end{array}$ & $\begin{array}{l}\geq 0.25-\leq 0.5 \% \text { cetrimonium } \\
\text { chloride }\end{array}$ & SM2 & 2.3:1 & $\begin{array}{c}1 \\
5 \\
10\end{array}$ & $\begin{array}{l}0.2[-0.3-0.6] \\
0.4[-0.1-0.8] \\
0.2[-0.2-0.6]\end{array}$ & $\begin{array}{l}\text { Yes (3/3) } \\
\text { Yes (3/3) } \\
\text { Yes (3/3) }\end{array}$ \\
\hline Panbio COVID-19 Ag Rapid Test Device Buffer (Abbott) & $\begin{array}{l}0.49 \% \\
\text { Tween-20 }\end{array}$ & PDRR & $3: 1$ & $\begin{array}{c}1 \\
5 \\
10 \\
\end{array}$ & $\begin{array}{l}0.2[-0.3-0.6] \\
0.6[0.1-1.0] \\
0.2[-0.2-0.7]\end{array}$ & $\begin{array}{l}\text { Yes }(3 / 3) \\
\text { Yes }(3 / 3) \\
\text { Yes }(3 / 3)\end{array}$ \\
\hline $\begin{array}{c}\text { Healgen Coronavirus Ag Rapid Test Cassette Swab Buffer } \\
\text { (Zhejiang Orient Gene) }\end{array}$ & Not known & PDRR & $3: 1$ & $\begin{array}{c}1 \\
5 \\
10\end{array}$ & $\begin{array}{l}0.8[0.4-1.2] \\
1.4[1.0-1.8] \\
1.6[1.2-2.0]\end{array}$ & $\begin{array}{l}\text { Yes }(3 / 3) \\
\text { Yes }(3 / 3) \\
\text { Yes }(3 / 3)\end{array}$ \\
\hline LumiraDx SARS-CoV-2 Ag Test Extraction Buffer (LumiraDx) & $\begin{array}{l}0.5 \% \text { unspecified detergent } \\
1.00 \% \text { Tween } 20\end{array}$ & PDRR & $7.5: 1$ & $\begin{array}{c}1 \\
5 \\
10 \\
\end{array}$ & $\begin{array}{l}-0.4[-0.9-0.0] \\
-0.5[-0.9--0.1] \\
-0.5[-1.0-0.0]\end{array}$ & $\begin{array}{l}\text { Yes }(3 / 3) \\
\text { Yes }(3 / 3) \\
\text { Yes }(3 / 3)\end{array}$ \\
\hline $\begin{array}{l}\text { COVID-19 (SARS-CoV-2) Antigen Test Kit Extraction Reagent } \\
\text { (Anhui Deepblue Medical Technology) }\end{array}$ & Not known & None & $3: 1$ & $\begin{array}{c}1 \\
5 \\
10\end{array}$ & $\begin{array}{l}0.0[-0.4-0.3] \\
0.0[-0.6-03] \\
0.1[-0.3-0.5]\end{array}$ & $\begin{array}{l}\text { Yes }(3 / 3) \\
\text { Yes }(3 / 3) \\
\text { Yes }(3 / 3)\end{array}$ \\
\hline Veritor Extraction Reagent (BD) & $0.1-<1 \%$ Triton $\mathrm{X}-100$ & PDRR & $3.25: 1$ & $\begin{array}{c}1 \\
5 \\
10 \\
\end{array}$ & $\begin{array}{l}\geq 4.5[4.2-4.8] \\
\geq 5.4[5.2-5.7] \\
\geq 5.7[5.4-6.0]\end{array}$ & $\begin{array}{l}\mathrm{No}^{3} \\
\mathrm{No}^{2} \\
\mathrm{No}^{1}\end{array}$ \\
\hline SARS-CoV-2 Quick ${ }^{\mathrm{TM}}$ Antigen Extraction Buffer (ScheBo) & $<1 \%$ Triton X-100 & PDRR & $2.5: 1$ & $\begin{array}{c}1 \\
5 \\
10 \\
\end{array}$ & $\begin{array}{c}5.3[5.1-5.6] \\
\geq 6.0[5.7-6.3] \\
\geq 6.0[5.7-6.3] \\
\end{array}$ & $\begin{array}{l}\text { Yes (3/3) } \\
\text { Yes (2/3) } \\
\mathrm{No}^{4} \\
\end{array}$ \\
\hline $\begin{array}{l}\text { Vstrip COVID-19 Antigen Rapid Test Extraction Buffer } \\
\text { (Panion \& BF Biotech) }\end{array}$ & $\begin{aligned} & <1 \% \text { Tergitol } \\
< & 1.2 \% \text { Methanol }\end{aligned}$ & PDRR & $10: 1$ & $\begin{array}{c}1 \\
10\end{array}$ & $\begin{array}{l}0.1[-0.3-0.4] \\
0.0[-0.5-0.3]\end{array}$ & $\begin{array}{l}\text { Yes }(3 / 3) \\
\text { Yes }(3 / 3)\end{array}$ \\
\hline $\begin{array}{c}\text { SARS-CoV-2 Antigen Qualitative Test Extraction Solution } \\
\text { (Innova) }\end{array}$ & Not known & None & $2: 1$ & $\begin{array}{c}1 \\
5 \\
10 \\
\end{array}$ & $\begin{array}{l}0.1[-0.3-0.5] \\
0.1[-0.2-0.5] \\
0.0[-0.5-0.4]\end{array}$ & $\begin{array}{l}\text { Yes }(3 / 3) \\
\text { Yes }(3 / 3) \\
\text { Yes }(3 / 3)\end{array}$ \\
\hline COVID-19 Rapid Antigen Test Sample Buffer (Mologic) & $0.4 \%$ unspecified surfactant & PDRR & $3.5: 1$ & 1 & $\geq 5.4[5.1-5.7]$ & $\mathrm{No}^{1}$ \\
\hline $\begin{array}{l}\text { Extraction Buffer from Standard Q COVID-19 Ag Test Kit } \\
\text { (SD Biosensor) }\end{array}$ & Not known & PDRR & $2: 1$ & $\begin{array}{c}1 \\
5 \\
10 \\
\end{array}$ & $\begin{array}{l}1.7[1.3-2.1] \\
2.4[2.0-2.8] \\
2.9[2.4-3.3]\end{array}$ & $\begin{array}{l}\text { Yes }(3 / 3) \\
\text { Yes }(3 / 3) \\
\text { Yes }(3 / 3) \\
\end{array}$ \\
\hline $\begin{array}{l}\text { Extraction Buffer from Standard Q COVID-19 Ag Saliva Test Kit } \\
\text { (SD Biosensor) }\end{array}$ & Not known & PDRR & $3.5: 1$ & $\begin{array}{c}1 \\
5 \\
10\end{array}$ & $\begin{array}{l}0.8[0.4-1.2] \\
1.1[0.7-1.6] \\
1.8[1.4-2.2]\end{array}$ & $\begin{array}{l}\text { Yes }(3 / 3) \\
\text { Yes }(3 / 3) \\
\text { Yes }(3 / 3)\end{array}$ \\
\hline
\end{tabular}

$3 \overline{21} \quad{ }^{*}$ As indicated on product safety data sheets or other product literature

322 tValues are given as $\geq$ when at least one replicate was below the limit of detection

323 łPDRR: Pierce Detergent Removal Resin; SM2: Biorad SM2 BioBeads;

324 Limit of detection: ${ }^{1} 1.0 \log _{10} \mathrm{TCID} \mathrm{D}_{50} / \mathrm{mL} ;{ }^{2} 1.3 \log _{10} \mathrm{TCID} 50 / \mathrm{mL} ;{ }^{3} 2.2 \log _{10} \mathrm{TCID} 50 / \mathrm{mL} ;{ }^{4} 0.7 \log _{10} \mathrm{TCID} \mathrm{D}_{50} / \mathrm{mL} ;{ }^{51.7} \log _{10} \mathrm{TCID} 50 / \mathrm{mL}$ 
